\title{
The Role of Positive Emotion and Contributions of Positive Psychology in Depression Treatment: Systematic Review
}

\author{
Veruska Santos ${ }^{1, *}$, Flavia Paes ${ }^{1}$, Valeska Pereira ${ }^{1}$, Oscar Arias-Carrión ${ }^{2}$, Adriana Cardoso Silva ${ }^{1}$, \\ Mauro Giovanni Carta ${ }^{6}$, Antonio Egidio Nardi ${ }^{1}$ and Sergio Machado $1,3,4,5$
}

${ }^{1}$ Laboratory of Panic and Respiration, Institute of Psychiatry of Federal University of Rio de Janeiro (IPUB/UFRJ), Rio de Janeiro, RJ, Brazil; National Institute for Translational Medicine (INCT-TM), Brazil

${ }^{2}$ Hospital General Dr. manuel Gea Gonzalez, Secretaria de Salud Mexico DF, Mexico

${ }^{3}$ Quiropraxia Program of Faculty of Health Sciences, Central University (UCEN), Santiago, Chile

${ }^{4}$ Institute of Philosophy, Federal University of Uberlandia (IFILO/UFU), Minas Gerais, Brazil

${ }^{5}$ Physical Activity Neuroscience Laboratory (LABNAF), Physical Activity Sciences Postgraduate Program of Salgado de Oliveira University (PPGCAF/UNIVERSO), Niterói, Brazil

${ }^{6}$ Department of Public Health and Clinical and Molecular Medicine, University of Cagliari, Italy

\begin{abstract}
The present study aims to conduct a systematic review of the literature by checking the impact of positive emotion in the treatment of depression and on the use of strategies of positive psychology which involves positive emotion to treat and reduce symptoms of depression. For this purpose, we conducted searches in databases ISI Web of Knowledge, PsycINFO and PubMed and found a total of 3400 studies. After inclusion application and exclusion criteria, 28 articles remained, presented and discussed in this study. The studies have important relations between humor and positive emotion as well as a significant improvement in signs and symptoms of depression using differents strategies of positive psychology. Another relevant aspect is the preventative character of the proposed interventions by positive psychology by the fact that increase well-being and produce elements such as resilience and coping resources that reduce the recurrent relapses in the treatment of depression. The strategies of positive psychology, such as increasing positive emotions, develop personal strengths: seeking direction, meaning and engagement for the day-to-day life of the patients, appear as potentially tools for the prophylaxis and treatment of depression, helping to reduce signs and symptoms as well as for prevention of relapses.
\end{abstract}

Keywords: Depression, emotion, positive psychology, resilience.

\section{INTRODUCTION}

Positive psychology is a psychological approach targeted to emphasize people skills and to promote their cognitive functioning, physical and emotional health. Martin Seligman, American psychologist, established in January 1998 the conceptual basis of positive psychology at the time he assumed the presidency of the American Psychological Association (APA). Seligman [1] stressed the fact that psychology needed to study also the human qualities and not only the weaknesses and illnesses. The focus of clinical psychology intervention was mental illness, understanding and how to reduce the signs and symptoms associated to psychiatric disorders. According to Wood and Tarrier [2] prior to the event of positive psychology the negative aspects of life were taken into consideration and the positive aspects were disregarded. These authors don't suggest the study of positive functioning as a separate field of clinical psychology, but

*Address correspondence to this author at the Laboratory of Panic and Respiration.Institute of Psychiatry - Federal University of Rio de Janeiro Brazil; Tel: +5521-2521-6147; Fax: +5521-2521-6147;

E-mail: veruskaasantos@gmail.com rather that clinical psychology itself changes to become a more integrative discipline.

Seligman, Steen, Parks \& Peterson [3] point out that positive psychology emphasizes the study of positive emotion, the personal strengths and skills of the human being, as wel as the positive institutions, which are institutions that allow the experience and expression of positive emotions such as the familiy and the community to enhance mental health and promote wellness. According to Sin \& Lyubormirsky [4], extending the positive emotion in daily life of patients is one of the main goals of positive psychology. Positive emotions as joy, gratitude, serenity, interest, hope, pride, amusement, inspiration, awe and love play a central role in the treatment and can function as a kind of protection against stress and depression. [5-8] pointed the importance of positive emotions on psychological well-being. [9-12] have shown that positive automatic thoughts and optimistic style of thinking also offers protection against depression and are indicators of happiness and well-being.

$[6,13-15]$ pointed an important aspect studied by positive psychology: resilience and how to make people more resilient in when facing adversity. Resilience refers to the 
capacity for successful adaptation or change in the face of adversity. Studies suggest several ways to achieve this goal. These authors noted the importance of developing resilience to manage depression and that it is supported by social support, affective ties and expansion of positive emotions. [10] stressed the role of positive cognitive triad in the development of resilience in life satisfaction and depression and reinforcing the positive cognitions are important factors to promote resiliency and well-being.

Positive psychology has been used to treat various mental disorders. In the treatment of depression, a model intervention was developed by Seligman, Rashid \& Parks [16] and they called it positive psychotherapy (PPT), aiming to increase objective and subjective welfare, positive emotion, positive behaviors and cognitions. [17] highlight the strategies of positive psychology are generating positive coping resources that alleviate depression and reduce their relapses.

Thus, the present study aims to conduct a systematic review of the literature on the impact of positive emotion in the treatment of depression and on the use of positive psychology strategies that involves positive emotion to treat and reduce symptoms of depression.

\section{METHODOLOGY}

\section{Eligibility criteria}

The methodology of this study will follow the PRISMA model (Preferred Reporting Items for Systematic reviews and Meta-Analyses) for the determination of eligibility.

1- Type of studies - The studies were randomized clinical trials, prospective cohort studies, cross-sectional observational studies and case-control studies in order to generate evidence regarding the effects and the impact of positive emotion in the treatment of depression;

2- Type of participants - no limitation of age, young women with depression or not;

3- Types of intervention - positive psychology strategies or emotion in evaluating patients with depression or not. Some articles compared these interventions to controlled groups by the symptoms of depression and the scores of depression scales.

4- Types of measures - depression, anxiety, mood, wellbeing, personality, quality of life, positive and negative affect, gratitude, hope, stress, resilience, life satisfaction, selfesteem, automatic thoughts, happiness, meaning, mindfulness were analyzed by using of specific scales.

\section{Sources of information}

The articles included in this study were selected in searches in the database ISI Web of Knowledge, PubMed and PsycINFO in September 2013, without restriction in any of the databases. From own references found in the electronic databases, it was also performed a manual search.

\section{Search}

All searches in databases used the terms "positive psychology", "emotion" and "depression".

\section{Selection of studies}

The selection of the studies was carried out by two independent authors, which in case of divergences have sought a consensus on the selection. The evaluation consisted in the filtering of the studies, from the analysis of the title, followed by summary and analysis after the full article. In need to solve possible disagreements between the two experts, a third evaluator was requested for the due order. Complete relevant articles were obtained and evaluated with inclusion and exclusion criteria, described below.

\section{Search of Data}

The following data was extracted from the articles: sample size, characteristics of participants, type of intervention, scales used, measurements of hope, happiness, wellbeing, depression, anxiety and others and meaningful main results. In addition to these, several other information about methods and results were collected. These procedures were performed by two independent investigators have reached a consensus in the case of divergence.

\section{Exclusion Criteria}

The articles that used interventions not associated with emotion, population with mental diseases differing from depression, specific samples composed of children, neurological disease, those who do not have detailed the procedure applied, or did not present results of variables emotion and humor.

\section{Risk of Bias in Studies}

For the assessment of risk of bias of each item included it was analyzed: the presence of eligibility criteria for participants of the sample; the random allocation of participants, the results of all times from the analysis of more than $85 \%$ of the sample, the presence of the control group, presentation of results and the variability of the results inter groups.

The flowdiagram is shown below (Fig. 1).

\section{RESULTS}

The categorization of the studies included in this study is presented below in accordance to the design of the studies (Table $\mathbf{1}$ and $\mathbf{2}$ ).

\section{CROSS-SECTIONAL OBSERVATIONAL STUDIES}

Cross-sectional observational studies were found in 7 articles. In the first, [18] investigated the relationship between personality, mood and memory. 62 individuals participated in three sessions where they were asked to encode adjectives that described themselves or not, for that, subjects heard a recording with 39 adjectives and on a sheet of paper where this 39 adjectives were written and followed by meanings, the subjects were asked to circulated if the adjective heard described themselves. The next moment, they were asked to recall many adjectives as they could in two minutes and write down as many of the adjectives as possible. After the recall task the participants were asked to fill out the following questionnaires: a short 18-item Profile of Mood States [19], Tension/ Anxiety (POMS T); Depression (POMS D) and Vigor (POMS V); State and Trait versions of the State 


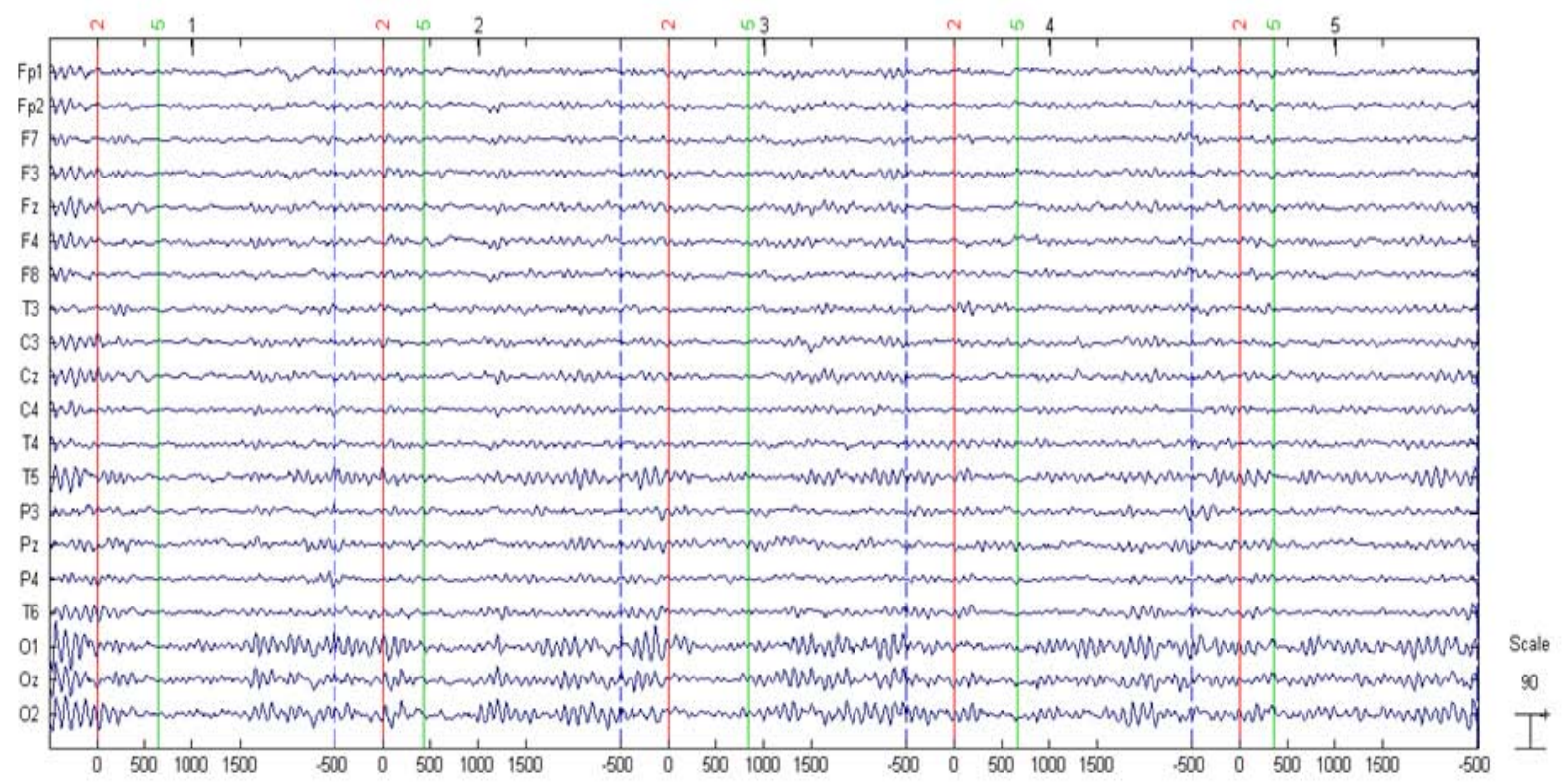

\section{baseline \\ stimulus appearance \\ movement}

Fig. (1). Flow diagram of selected studies.

Table 1. Summary of Prospective Cohort, Cross-Sectional Observational and Case-Control Studies on the Role of Positive Emotion and Contributions of Positive Psychology in Depression Treatment

\begin{tabular}{|c|c|c|c|c|}
\hline Authors & Objective & $\mathbf{N}$ & Design & Main Results \\
\hline $\begin{array}{c}\text { Lewin- } \\
\text { sohn,PM;Libet,J. }\end{array}$ & $\begin{array}{l}\text { Investigate the relationship } \\
\text { between humor and pleas- } \\
\text { ant activities. }\end{array}$ & 30 & $\begin{array}{l}\text { Prospective cohort } \\
\text { study }\end{array}$ & $\begin{array}{l}\text { Three groups of } 10 \text { subjects (depression, psychiatric and } \\
\text { control) during } 30 \text { consecutive days engaged in enjoyable } \\
\text { activities and measured their mood. The results showed a } \\
\text { significant association between pleasant activities and mood } \\
\text { state suggesting a clinical utility. }\end{array}$ \\
\hline Lightsey,O.R. & $\begin{array}{l}\text { Evaluate if automatic posi- } \\
\text { tive thoughts could function } \\
\text { as protective factors to } \\
\text { stress and depression. }\end{array}$ & 152 & $\begin{array}{l}\text { Prospective cohort } \\
\text { study }\end{array}$ & $\begin{array}{l}\text { The results confirmed the hypothesis that automatic positive } \\
\text { thoughts are predictors of happiness and higher frequency } \\
\text { of them was associated with greater future happiness. This } \\
\text { findings suggests that positive automatic thoughts had an } \\
\text { impact on immediate and on future well-being alleviating } \\
\text { depression. }\end{array}$ \\
\hline $\begin{array}{l}\text { Kuppens,P } \\
\text { Nezlek,J.B, }\end{array}$ & $\begin{array}{l}\text { Examine how subjects } \\
\text { regulated their emotions in } \\
\text { daily life and how this } \\
\text { affected their emotional } \\
\text { experiences and their psy- } \\
\text { chological adjustment. }\end{array}$ & 153 & $\begin{array}{c}\text { Prospective cohort } \\
\text { study }\end{array}$ & $\begin{array}{l}\text { Over the course of three weeks participants described as } \\
\text { they had adjusted the emotion in terms of reassessment or } \\
\text { inhibition of positive and negative emotions. The results } \\
\text { showed that the reappraisal situations to increase positive } \\
\text { emotions was positively related to self-esteem, psychologi- } \\
\text { cal adjustment and positive affect, in contrast, supressing } \\
\text { the expression of positive emotions was associated with } \\
\text { decreased self-esteem, decreased psychological adjustment } \\
\text { and increased negative emotions. These analyses suggested } \\
\text { that positive and negative emotion played diferentes roles in } \\
\text { mediating the psychologycal adjustment and self-esteem. }\end{array}$ \\
\hline
\end{tabular}


Table 1. contd....

\begin{tabular}{|c|c|c|c|c|}
\hline Authors & Objective & $\mathbf{N}$ & Design & Main Results \\
\hline $\begin{array}{c}\text { Saw- } \\
\text { yer,M.G;Pfeiffer,S; } \\
\text { Spence,S.H. }\end{array}$ & $\begin{array}{l}\text { Investigate the impacts of } \\
\text { positive and negative man- } \\
\text { agement strategies and } \\
\text { optimistic thinking style in } \\
\text { depressive symptoms. }\end{array}$ & 5634 & $\begin{array}{l}\text { Prospective cohort } \\
\text { study }\end{array}$ & $\begin{array}{l}\text { The results showed that teens who made greater use of } \\
\text { negative coping strategies and less use of positive coping } \\
\text { strategies and optimistic thinking were at increased risk for } \\
\text { higher levels of depressive symptoms. This findings suggest } \\
\text { that negative life events and negative coping strategies } \\
\text { precede and likely contribute to the onset of depressive } \\
\text { symptoms while positive coping strategies and optimistic } \\
\text { thinking may have a protective effect against depression. }\end{array}$ \\
\hline $\begin{array}{l}\text { Wenze,S.J.; } \\
\text { Gunthert,K,. \& } \\
\text { Forand,N.R. }\end{array}$ & $\begin{array}{l}\text { Analize the relationship } \\
\text { between cognitive reactivity } \\
\text { (relationship between } \\
\text { thought and mood) and } \\
\text { depression. }\end{array}$ & 63 & $\begin{array}{l}\text { Prospective cohort } \\
\text { study }\end{array}$ & $\begin{array}{l}\text { The results pointed out that cognitive reactivity remained } \\
\text { predictive of follow-up depressive symtom scores ( } \mathrm{p}<0.05 \text { ) } \\
\text { and accounted for } 6.1 \% \text { of the variance in follow-up depres- } \\
\text { sive symptom. Dysfunctional atitudes were predictive of } \\
\text { follow-up depressive symptom, controlling for initial de- } \\
\text { pressive symptom ( } \mathrm{p}=0.06 \text { ) and account for } 5.5 \% \text { of the } \\
\text { variance in folow-up depressive symptoms. Cognitive reac- } \\
\text { tivity was somewhat more predictive of follow-up depres- } \\
\text { sive symptom scores in participants who had experienced } \\
\text { high levels of life stress. This results indicate that cognitive } \\
\text { reactivity serves as a risk fator for the development of de- } \\
\text { pressive symtoms. }\end{array}$ \\
\hline $\begin{array}{l}\text { Mauss,I.B.; Shall- } \\
\text { cross,A.J;Troy,A.S.; } \\
\text { John,O.P.; Ferrer,E.; } \\
\text { Wilhelm,F.H. } \\
\text { Gross,J.J. }\end{array}$ & $\begin{array}{l}\text { Examine whether dissocia- } \\
\text { tion between positive emo- } \\
\text { tion experience and behav- } \\
\text { iors predicts two facets of } \\
\text { psychological functioning- } \\
\text { depressive symptoms and } \\
\text { well-being- and if so, wether } \\
\text { these effects are mediated by } \\
\text { social connectedness. }\end{array}$ & 135 & $\begin{array}{l}\text { Prospective cohort } \\
\text { study }\end{array}$ & $\begin{array}{l}\text { The results showed that positive experience-behavior disso- } \\
\text { ciation predicted social connectedness }(\mathrm{p}<0.05 \text { ); social } \\
\text { connectedness was negatively associated with depressive } \\
\text { symptoms }(\mathrm{p}<0.05 \text { ) and positively associated with well- } \\
\text { being ( }<0.05 \text { ). This study showed that the more partici- } \\
\text { pants positive experience and behaviors were dissociated } \\
\text { during a positive emotion induction, the greater levels of } \\
\text { depressive symptoms and the lower levels of well-being } \\
\text { participants experienced six months later. }\end{array}$ \\
\hline $\begin{array}{c}\text { Catalino,L.I \& } \\
\text { Fredrickson,B.L. }\end{array}$ & $\begin{array}{l}\text { Evaluate whether and how } \\
\text { routine activity promote } \\
\text { flourishing - a state of op- } \\
\text { timal mental health. }\end{array}$ & 208 & $\begin{array}{l}\text { Prospective cohort } \\
\text { study }\end{array}$ & $\begin{array}{l}\text { Comparing florishers to depressed and non florishers the } \\
\text { authors discovered that flourishers respond more positively } \\
\text { to pleasant activities, ranging from interacting to learning. } \\
\text { The analysis pointed out important differences in florishers } \\
\text { individuals in positive emotionality that modify signifi- } \\
\text { cantly the capabilities of coping and feeling of well being } \\
\text { and that the maintenance of this blossoming is the impor- } \\
\text { tance given to ordinary everyday experiences as, for exam- } \\
\text { ple, chat with a colleague, helping, interacting, playing, } \\
\text { learning, spiritual activity and exercising. }\end{array}$ \\
\hline $\begin{array}{c}\text { Gruber,J.; Kogan,A.; } \\
\text { Quoidbach,J.; \& } \\
\text { Mauss,I.B. }\end{array}$ & $\begin{array}{l}\text { Examine the Psychological } \\
\text { health correlates of positive } \\
\text { emotion variability versus } \\
\text { stability. }\end{array}$ & $\begin{array}{c}\mathrm{N}^{1} 244 \\
\mathrm{~N}^{2} 2391\end{array}$ & $\begin{array}{l}\text { Prospective cohort } \\
\text { study }\end{array}$ & $\begin{array}{l}\text { In Study } 1 \text { participants who experienced greater positive } \\
\text { emotion variability throughout the } 14 \text { day period reported } \\
\text { worse Psychological health including decreased life satis- } \\
\text { faction and increased depression and anxiety }(\mathrm{ps}<0.05) \text {. In } \\
\text { study } 2 \text { participants who reported greater positive emotion } \\
\text { variability throughout the previous day reported worse } \\
\text { Psychological health and decreased daily and life satisfac- } \\
\text { tion and subjective happiness.(ps }<0.01) \text {. }\end{array}$ \\
\hline
\end{tabular}


Table 1. contd....

\begin{tabular}{|c|c|c|c|c|}
\hline Authors & Objective & $\mathbf{N}$ & Design & Main Results \\
\hline $\begin{array}{l}\text { Bradley,B.P. \& } \\
\text { Mogg,K. }\end{array}$ & $\begin{array}{l}\text { Ascertain the relationship } \\
\text { between personality, mood } \\
\text { and memory. }\end{array}$ & 62 & $\begin{array}{c}\text { Cross-sectional } \\
\text { observational study }\end{array}$ & $\begin{array}{l}\text { The results showed a tendency to remember negative in- } \\
\text { formation in subjects with depressive mood and personality } \\
\text { vulnerabilities. }\end{array}$ \\
\hline $\begin{array}{l}\text { Lawton,M,P,Winter, } \\
\text { L, } \\
\text { Kleban,M.H,Ruckde } \\
\text { schel,K }\end{array}$ & $\begin{array}{l}\text { Determine the contribution } \\
\text { of objective and subjective } \\
\text { quality of life as positive } \\
\text { and negative indicators of } \\
\text { mental health in a sample of } \\
\text { people of the third age. }\end{array}$ & 602 & $\begin{array}{c}\text { Cross-sectional } \\
\text { observational study }\end{array}$ & $\begin{array}{l}\text { The senior-center subjects were more depressed, had less } \\
\text { contact with relatives and had lower activity participantion } \\
\text { than housing residentes, but other model elements were not } \\
\text { diferent. The study demonstrated that participation in objec- } \\
\text { tive activities, the quality of friendships and family are } \\
\text { associated with positive affection and that quality time is } \\
\text { associated with both positive affect and depression. }\end{array}$ \\
\hline $\begin{array}{l}\text { Dowrick,C, Kokano- } \\
\text { vic,R,Hegarty,K, } \\
\text { Griffiths,F, Gunn,J }\end{array}$ & $\begin{array}{l}\text { Verifie the importance of } \\
\text { developing resilience to } \\
\text { handle depression in } 100 \\
\text { depressive subjects met in } \\
\text { emergency services of } \\
\text { hospitals in Australia. }\end{array}$ & 100 & $\begin{array}{c}\text { Cross-sectional } \\
\text { observational study }\end{array}$ & $\begin{array}{l}\text { One-third of the subjects developed sustained resilience by } \\
\text { personal resources consisting of internal forces and another } \\
\text { third of the sample sustained their resilience in the expan- } \\
\text { sion of positive emotions. The personal resilience appears } \\
\text { to be important in patients with experience of depressive } \\
\text { symptoms in primary care. }\end{array}$ \\
\hline $\begin{array}{l}\text { Wood,A.M.;Maltby,J } \\
\text {; Gillett,R; Lin- } \\
\text { ley,P.A.\&Joseph,S }\end{array}$ & $\begin{array}{l}\text { Analyze the role of grati- } \\
\text { tude in the perception of } \\
\text { social support, stress and } \\
\text { depression. }\end{array}$ & $\begin{array}{l}N^{1} 156 N^{2} \\
87 N=243\end{array}$ & $\begin{array}{c}\text { Cross-sectional } \\
\text { observational study }\end{array}$ & $\begin{array}{l}\text { The results confirmed that the gratitude leads to well-being } \\
\text { and social support above the effects of Big Five. It suggests } \\
\text { a role for gratitude in well-being and social life protecting } \\
\text { people from stress and depression even under the effects of } \\
\text { the dimensions given in the personality test. }\end{array}$ \\
\hline $\begin{array}{l}\text { Liu,Q; Shono,M; } \\
\text { Kitamura,T. }\end{array}$ & $\begin{array}{l}\text { investigate the relationship } \\
\text { between psychological } \\
\text { well-being with depression } \\
\text { and anxiety. }\end{array}$ & 545 & $\begin{array}{c}\text { Cross-sectional } \\
\text { observational study }\end{array}$ & $\begin{array}{l}\text { The analysis of the results pointed out that people with } \\
\text { greater psychological well-being are more resilient and } \\
\text { more resistant to adversity that people with low levels of } \\
\text { psychological well-being. In this way, this study could } \\
\text { provide an useful implication for clinical work in psycho- } \\
\text { therapy on well-being promotion to prevent and treat de- } \\
\text { pression and anxiety. }\end{array}$ \\
\hline $\begin{array}{l}\text { Vranceanu,A-M; } \\
\text { Gallo,L.C.\& } \\
\text { Bogart,L.M. }\end{array}$ & $\begin{array}{l}\text { Evaluate the association } \\
\text { between personal experi- } \\
\text { ences, the fleeting affec- } \\
\text { tions and depressive symp- } \\
\text { toms in women }\end{array}$ & 108 & $\begin{array}{c}\text { Cross-sectional } \\
\text { observational study }\end{array}$ & $\begin{array}{l}\text { Women with higher levels of depression reported greater } \\
\text { negative affect, less positive affect and more interpersonally } \\
\text { conflictive interactions across two days of diary monitoring. } \\
\text { According to the authors, social interations are strong con- } \\
\text { tributors to the relationship between depressive symptoms } \\
\text { and affect suggesting that interpersonal functioning as a key } \\
\text { fator in etiology and maintenance of depression. }\end{array}$ \\
\hline $\begin{array}{l}\text { Mak,W.W., } \\
\text { Ng,I.S.W. \& } \\
\text { Wong,C.C.Y. }\end{array}$ & $\begin{array}{l}\text { Estabilish the role of posi- } \\
\text { tive cognitive triad in the } \\
\text { development of resilience in } \\
\text { life satisfaction and depres- } \\
\text { sion in a sample of } 1419 \\
\text { university students in Hong } \\
\text { Kong. }\end{array}$ & 1419 & $\begin{array}{c}\text { Cross-sectional } \\
\text { observational study }\end{array}$ & $\begin{array}{l}\text { The study revealed that positive cognitions are important } \\
\text { factors that contribute to the effect of trait resilience on } \\
\text { well-being. Educators and psychologists may consider } \\
\text { cognitive mechanisms to promote resiliency and well-being. }\end{array}$ \\
\hline $\begin{array}{c}\text { Alloy,LB, Crocker,J, } \\
\text { Kayne,NT }\end{array}$ & $\begin{array}{l}\text { Check whether there would } \\
\text { be differences in percep- } \\
\text { tions of consensus for posi- } \\
\text { tive, negative and neutral } \\
\text { events in depressive and } \\
\text { non-depressive and the } \\
\text { effects of these interpreta- } \\
\text { tions both on attributive } \\
\text { style and on levels of de- } \\
\text { pression. }\end{array}$ & 52 & Case-control study & $\begin{array}{l}\text { The depression is not affected by the perception of others } \\
\text { but by the perceptions of the self that have a direct associa- } \\
\text { tion with depression and an effect mediated through attribu- } \\
\text { tional style for negative events. The authors pointed out the } \\
\text { importance for the development of prevention and treatment } \\
\text { strategies to determinate the causes of a depressive attribu- } \\
\text { tional style. }\end{array}$ \\
\hline
\end{tabular}


Table 1. contd....

\begin{tabular}{|c|c|c|c|c|}
\hline Authors & Objective & $\mathbf{N}$ & Design & Main Results \\
\hline $\begin{array}{c}\text { Shee- } \\
\text { ber,L.B;Allen,N.B; } \\
\text { Leve,C; Davis,B; } \\
\text { Shortt,J,W; Katz,L,F. }\end{array}$ & $\begin{array}{l}\text { Delineate the dimensions of } \\
\text { affective experience in } \\
\text { depressive disorder in ado- } \\
\text { lescents. The affect regula- } \\
\text { tion involved in initiating, } \\
\text { maintaining and moduling } \\
\text { the occurence, intensity and } \\
\text { duration of the experience. }\end{array}$ & 152 & Case-control study & $\begin{array}{l}\text { The depressed adolescents didn't maintain happy affective } \\
\text { states for as long a time as the healthy ones }(\mathrm{p}<0.01) \text {. The } \\
\text { authors highlight the deficit of maintenance of positive } \\
\text { affect and the longer duration of physiological responses } \\
\text { associated with negative affect as a critical mechanism in } \\
\text { depression. }\end{array}$ \\
\hline $\begin{array}{c}\text { Levens,S.M \& Got- } \\
\text { lib,I.H. }\end{array}$ & $\begin{array}{l}\text { Verify whether depressed } \\
\text { participants were also im- } \\
\text { paired at selecting relevant } \\
\text { positive content in the con- } \\
\text { text of representations in } \\
\text { working memory (WM) } \\
\text { such an impairment would } \\
\text { limit depressed person's } \\
\text { ability to use positive mate- } \\
\text { rial to ameliorate the cogni- } \\
\text { tive effects of negative } \\
\text { information. }\end{array}$ & 42 & Case-control study & $\begin{array}{l}\text { The results presented that for the nondepressed participants, } \\
\text { interferences levels differed significantly across conditions } \\
(\mathrm{p}<0.001) \text { and this participants exhibited lower levels of } \\
\text { interference in the emotion focus condition in the neutral } \\
\text { and the emotion nonfocus conditions ( } \mathrm{p}<0.001) \text {. For the } \\
\text { depressed group levels did not differ across conditions } \\
(\mathrm{p}>0.05) \text { and this participants exhibited higher interference } \\
\text { levels than did their nondepressed peers in the emotion } \\
\text { focus condition ( }<<0.01) \text {. Nondepressed participants } \\
\text { showed less interference for positive than for neutral infor- } \\
\text { mation and depressed subjects showed equivalent levels of } \\
\text { interference for positive and neutral stimuli. }\end{array}$ \\
\hline
\end{tabular}

Legend: ANEW: Battery of English Words of Affective Contents; BDI: Beck Depression Inventory; BDI - II: Beck Depression Inventory II; BAI: Beck Anxiety Inventory; CES-D Center for Epidemiological Studies - Depression Measure; DAS: Dysfunctional Attitudes Scale; DRM: Day Reconstruction Method; EAT: The Computerized Edinburgh Associative Thesaurus; EES: Elevating Experience Scale; ERM: Ego-Resilience Measure; ESM: Computerized Experience-Sampling-Method; HS: Hope Scale; Life: Structure Card-Sorting Task; LOT: Life Orientation Test; MAS: Mindfulness and Awareness Scale; MS: Meaning Scale; PANAS: Positive Affect and Negative Affect; PWB: Psychological Well-Being Scale; SBI: Savoring Beliefs Inventory; SCID-I: Structured Clinical Interview for DSM IV-TR Axis I Disorders; SES: Self- Esteem Scale; SH I: Steen Happiness Index; STAI: Spielberger State-Trait Anxiety Inventory; SVS: Subjective Vitality Scale; SWLS: Satisfaction With Life Scale; VIA-IS: Values in Action Inventory of Strengths

Table 2. Summary of Randomized Control Trials Studies on The Role of Positive Emotion and Contributions of Positive Psychology in Depression Treatment

\begin{tabular}{|c|c|c|c|c|}
\hline Authors & Objctive & $\mathbf{N}$ & Delineation & Results \\
\hline $\begin{array}{l}\text { Beck, J.T., Strong, } \\
\text { S.R. } \\
(1982)\end{array}$ & $\begin{array}{l}\text { Check the effect of the } \\
\text { communication of the } \\
\text { therapist on the symptoms } \\
\text { of depressive patients. }\end{array}$ & 30 & $\begin{array}{l}\text { Randomized } \\
\text { Clinical Trial }\end{array}$ & $\begin{array}{l}\text { Depressed subjects were given brief therapy with positive conno- } \\
\text { tations and interpretations, with negative connotations and a } \\
\text { control group. Although all groups decreased depressive symp- } \\
\text { toms, the group that received negative interpretations did not } \\
\text { continue treatment while receiving positive interpretation per- } \\
\text { sisted in the treatment and have remitted the symptoms. The } \\
\text { scales used were: BDI Scale, Personal Mood Inventory and Bar- } \\
\text { rett-Lennard's Relashionship Inventory. The degree of signifi- } \\
\text { cance of personal impression was } p<0,001 \text { of controllability was } \\
\mathrm{p}<0,005 \text {, expectation for change was } \mathrm{p}<0,05 \text { and } \mathrm{p}<0,01 \text {. In the } \\
\text { inventory of relationships the } \mathrm{p} \text { was }<0,05 \text { and the only dimension } \\
\text { that presented variation was the resistance with } \mathrm{p}<0,005 \text {. In the } \\
\text { BDI the } \mathrm{p} \text { was }<0,005 \text { and }<0,001 \text {. The significance between } \\
\text { treatment and duration time and between the positive and nega- } \\
\text { tive connotations presented } \mathrm{p}<0,05 \text {. }\end{array}$ \\
\hline $\begin{array}{l}\text { Joormann et al. } \\
\qquad(2005)\end{array}$ & $\begin{array}{l}\text { Evaluate the ability to } \\
\text { intentionally forget nega- } \\
\text { tive material between de- } \\
\text { pressive and non- } \\
\text { depressive. }\end{array}$ & 72 & $\begin{array}{l}\text { Randomized } \\
\text { Clinical Trial }\end{array}$ & $\begin{array}{l}\text { Depressive participants could forget the negative responses and } \\
\text { the more they practiced the intentional forgetting of negative } \\
\text { material less basic items they resembled on the final test. Used } \\
\text { the BDI-II ( } P>0,10 \text { for the depressed group and } p>0,50 \text { for not } \\
\text { depressed) and the Battery of English Words of Affective Con- } \\
\text { tents. The practice of suppressing negative words by depressed } \\
\text { presented } p<0,025 \text { and the memory of the words from the base- } \\
\text { line } p<0,03 \text { for all groups. }\end{array}$ \\
\hline
\end{tabular}


Table 2. contd....

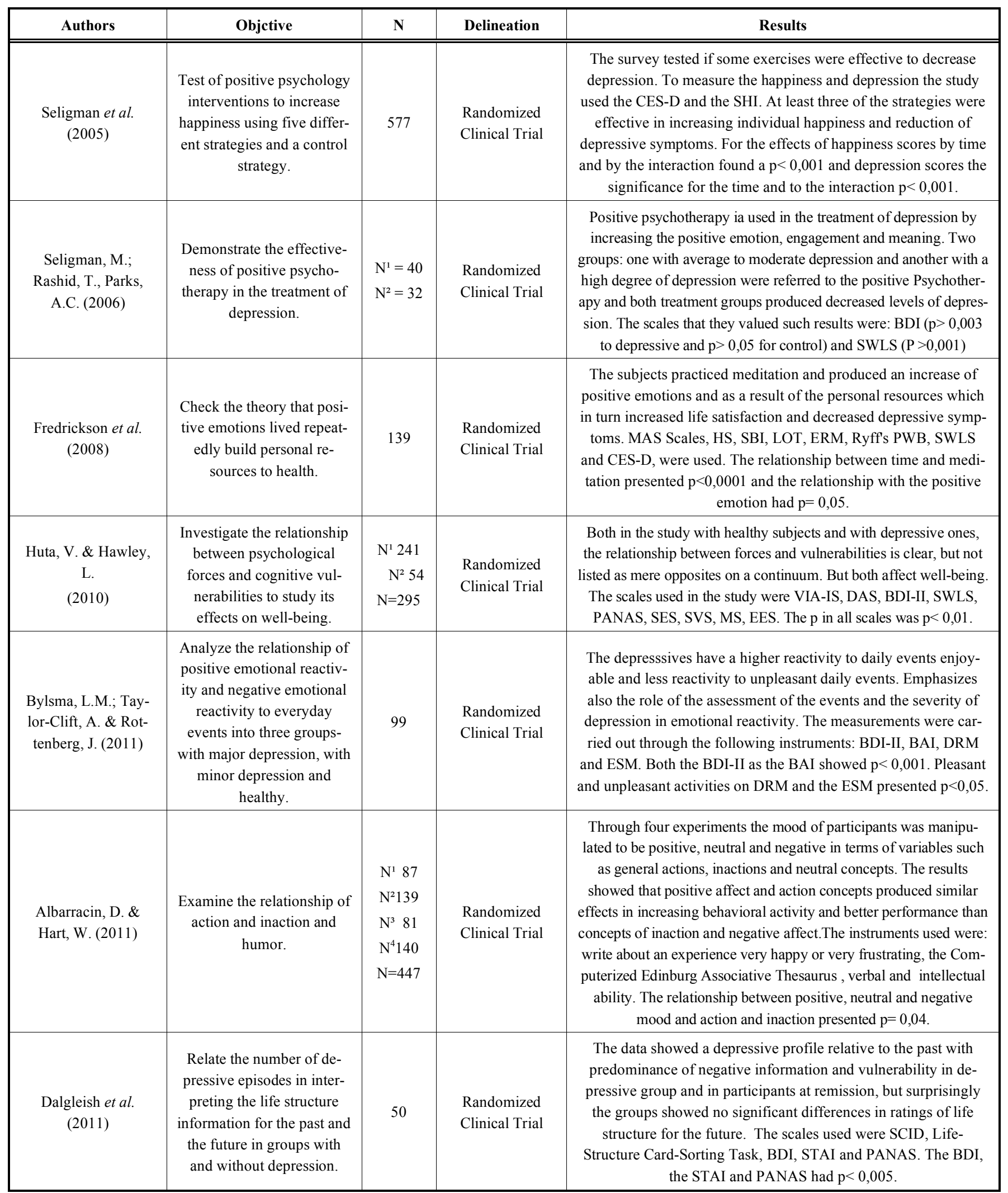

ANEW: Battery of English Words of Affective Contents; BDI: Beck Depression Inventory; BDI - II: Beck Depression Inventory II; BAI: Beck Anxiety Inventory; CES-D: Center for Epidemiological Studies - Depression Measure; DAS: Dysfunctional Attitudes Scale; DRM: Day Reconstruction Method; EAT: The Computerized Edinburgh Associative Thesaurus; EES: Elevating Experience Scale; ERM: Ego-Resilience Measure; ESM: Computerized Experience-Sampling-Method; HS: Hope Scale; Life: Structure Card-Sorting Task; LOT: Life Orientation Test; MAS: Mindfulness and Awareness Scale; MS: Meaning Scale; PANAS: Positive Affect and Negative Affect; PWB: Psychological Well-Being Scale; SBI: Savoring Beliefs Inventory; SCID-I: Structured Clinical Interview for DSM IV-TR Axis I Disorders; SES: Self- Esteem Scale; SH I: Steen Happiness Index; STAI: Spielberger State-Trait Anxiety Inventory; SVS: Subjective Vitality Scale; SWLS: Satisfaction With Life Scale; VIA-IS: Values in Action Inventory of Strengths 
Trait Anxiety inventory ( STAI - [20]); The Beck Depression Inventory (BDI; [21]) and The Eysenck Personality Questionnaire (EPQ; [22]) wich comprises Neuroticism, Extraversion, Psychoticism and Lie Scales. The results showed a tendency to remember negative information in subjects with depressive mood and personality vulnerabilities.

Lawton et al. [23] evaluated the contribution of objective quality of life (measured by amount of external social development indicators) and subjective (personal judgment of satisfaction) with aspects of development as positive and negative indicators of mental health in 602 elderly subjects from senior-center and several housing environments volunteeres who responded to the Philadelphia Geriatric Center Multilevel Assessment Instrument (MAI; Lawton, Moss, Fulcomer \& Kleban; [24]). To measure objective quality of life (OQOL) the composites indices of MAI relating familiy contact, friends contact and activity participation such as religious attendance, movies, playing cards, eating out or gardening were included. Subjective quality of life (SQOL) was measured by family quality (how much do your relatives make you feel loved and cared for?) by the time quality with interviews about daily aspects of their lives with such questions: How often you want your day to be shorter? Almost everthing I do each day is enjoyable (The ajusted goodnessof-fit-index (AGFI; [25]). The senior-center subjects were more depressed, had less contact with relatives and had lower activity participantion than housing residentes, but other model elements were not diferent. The study demonstrated that participation in objective activities, the quality of friendships and family are associated with positive affection and that quality time is associated with both positive affect and depression.

Dowrick et al. [13] verified the importance of developing resilience to handle depression in 100 depressive subjects met in emergency services of hospitals in Australia. After the emergency care, subjects responded to semi-structured telephone interviews - CATI (Computer Assisted Telephone Interview), lasting an hour, held by phone that addressed participation in depressive experiences, views of the causes of stress, ways to manage depression and stress, social support and health service use. The article focused on the answers given to three specific questions: when did you first realize that you had a depressive stress process or concern and what did you firstly decide to do? Is there anything else that you have tried to do to minimize depression, stress or concern? All that was attempted, what was the most useful? The authors assesed how respondents rate personal resilience when comparing to help received from professional sources. The analysis of the responses claimed that one-third of the subjects presented evidence of resilience supported by social and affective ties. One-third of the subjects developed sustained resilience by personal resources consisting of internal forces and another third of the sample sustained their resilience in the expansion of positive emotions. The personal resilience appears to be important in patients with experience of depressive symptoms in primary care.

Wood et al. [8] analyzed the role of gratitude in the perception of social support, stress and depression through two studies. In the first study 156 students responded to The Gratitude Questionnaire-6 (GQ-6; [26]) and Social Support sub-scale of the college student version of the Interpersonal Support Evaluation List (; [27]) and underwent tests as The Center for Epidemiological Studies Depression Scale (CESD; [28]) and The Perceived Stress Scale (PSS; Cohen \& Williamson; [29]). The results showed that gratitude lead to improving levels of social support, promotes lower levels of stress and depression over time. In study two, 87 students have completed the same tests and questionnaires from the study one, plus The Big Five Personality Inventory (BFI; [30]). The results confirmed that the gratitude leads to wellbeing and social support above the effects of Big Five. It suggests a role for gratitude in well-being and social life protecting people from stress and depression even under the effects of the dimensions given in the personality test.

Liu, Shono \& Kitamura [15] conducted a study to investigate the relationship between psychological well-being with depression and anxiety. 545 Japanese University students responded to Subjective Well-Being Scale of Ryff's (SPWB- [31]) and The Hospital Anxiety and Depression Scale (HADS- [32]). All six dimensions of the scales of Psychological Well-being Inventory (Autonomy - AU, Environment Mastery - EM, Personal growth- PG, Positive relationships with others- PR, Purpose of life - PL and Selfacceptance - AS) were moderately negatively correlated with depression and anxiety. The analysis of the results pointed out that people with greater psychological well-being are more resilient and more resistant to adversity that people with low levels of psychological well-being. In this way, this study could provide a useful implication for clinical work in psychotherapy on well-being promotion to prevent and treat depression and anxiety.

In another study, [33] evaluated the association between personal experiences, the fleeting affections and depressive symptoms in women, for that, it was used Ecological Momentary Assessment (EMA-[34]), The Center for Epidemiologic Study of Depression Scale (CES-D; [28]) and handheld computer containing a diary 39 likert-type scale items assessing affect, and the nature of the current or most recent social interaction derived from the Diary of Ambulatory Behavioral States to test the associations among depressive symptoms, social experiences and momentary affect in 108 women that were recruited for two consecutive days of registration on a portable computer their social interactions, their emotional experiences and their depressive symptoms, 50 in 50 minutes, from the time they woke up until the time of sleep. The participants answered questions about mood on their social interactions. Women with higher levels of depression reported greater negative affect, less positive affect and more interpersonally conflictive interactions across two days of diary monitoring. According to the authors, social interactions are strong contributors to the relationship between depressive symptoms and it affects suggesting that interpersonal functioning is a factor key in etiology and maintenance of depression.

Mak, Ng \& Wong [10] investigated the role of positive cognitive triad in the development of resilience in life satisfaction and depression in a sample of 1419 university students in Hong Kong. The subjects responded to the following on line tests: The Ego-Resilience Scale [35]; The Chinese version of 10-item Rosemberg Self-Esteem Scale [36]; 
The 10 item View of the World Scale a Subscale of The Cognitive Triad Inventory [37]; The six- item State Hope Scale [38]; Satisfaction With Life Scale (SWLS; [39]) and The Beck Depression Scale II (BDI-II; [40]) where they were analyzed levels of resilience, vision of themselves, vision of the world, vision of future, life satisfaction and depression. The study revealed that positive cognitions are important factors that contribute to the effect of trait resilience on well-being. Educators and psychologists may consider cognitive mechanisms to promote resiliency and well-being.

\section{PROSPECTIVE COHORT STUDIES}

The first prospective cohort study was conducted by Lewinsohn \& Libet [41], in order to investigate the relationship between humor and pleasant activities. 30 students were divided into three groups of ten components each. A group was composed of depression, another with anxious disorders or other disorders different from depression and a control group. The participants aswered The Pleasant Events Schedule [42] choosed one of the 320 events or activities to engage and at the end of the day, the students indicated in wich activity they had been engaged and their humor was evaluated through The Depression Adjective Check List [43]. The subjects were followed for 30 consecutive days and the study showed a significant association between pleasant activities and mood state suggesting a clinical utility to identify a small number of important activities which are related to the patient's mood state.

Lightsey [9] evaluated if automatic positive thoughts could function as protective factors to stress and depression. 152 volunteers underwent two testing sessions, one at the beginning of the research and another six weeks later. The testing used was The Beck Depression Scale (BDI; [21]), Automatic Thoughts Questionnaire - Positive (ATQP; [44]), Automatic Thoughts Questionnaire (Hollon \& Kendall [45]), Life Experience Survey (LES; [46]), The Hassles Scale (HS; [47]) and Happiness Measures (HM; [48]). The interval of six weeks provided the occurrence of stress in the daily life of individuals. The subjects returned for a new follow-up testing three months after. The results confirmed the hypothesis that automatic positive thoughts are predictors of happiness and higher frequency of them was associated with greater future happiness. These findings suggest that positive automatic thoughts had an impact on current and on future well-being. In view of these findings, clinical treatment would focus on increasing patients' positive automatic thoughts which may help to increase happiness and reducing negative automatic toughts may be important for alleviating depression.

Nezlek \& Kuppens [49] examined how 153 subjects regulated their emotions in daily life and how this affected their emotional experiences and their psychological adjustment. For three weeks the participants described as they had adjusted their emotions in terms of reappraisal (consists of changing the interpretation of the situation to lessen the emotional impact) or supression (consists of inhibit external reactions of feelings) of positive and negative emotions and qualified as reevaluating or suppressing the emotional experience according to the model proposed by Gross and John [50] using the following items for reappraisal: "When I try to feel more or less positive emotions I change what I'm thinking about..." and for deletion: "When I feel positive or negative emotion I take care not to express...". Self-esteem was measured by Rosemberg Self-Esteem Scale [36] and its psychological adjustment in accordance with Beck's cognitive triad for depression of vision of itself, and future sight. The results showed that the reappraisal situations to increase positive emotions was positively related to self-esteem, psychological adjustment and positive affect, in contrast, supressing the expression of positive emotions was associated with decreased self-esteem, decreased psychological adjustment and increased negative emotions. These analyses suggested that positive and negative emotion played diferentes roles in mediating the psychologycal adjustment and selfesteem.

Sawyer, Pfeiffer \& Spence [11] accompanied 5089 teenagers for one year to investigate the impacts of positive and negative management strategies (ways how people react in the face of situations, behavioral aspect) and optimistic thinking style in depressive symptoms (cognitive aspect). So, it was used the following instruments: The Center for Epidemiological Studies Depression Scale (CES-D; [28]); List of Threatening Experiences Questionnaire (LTE-Q; [51]); Social Problem Solving Inventory - Revised (SIPS-R; [52]); The Self Reporting Coping Scale (SRCS; [53]) and Optimistic Thinking Style ("Beyondblue Schools Research Initiative" [54]). The results showed that teens who made greater use of negative coping strategies and less use of positive coping strategies and optimistic thinking were at increased risk for higher levels of depressive symptoms. These findings suggest that negative life events and negative coping strategies precede and likely contribute to the onset of depressive symptoms while positive coping strategies and optimistic thinking may have a protective effect against depression.

Wenze, Gunthert \& Forand [55] investigated the relationship between cognitive reactivity (relationship between thought and mood) and depression. 63 students of Psychology replied to tests: The Center for Epidemiological Studies Depression Scale (CES-D; [28]), The Dysfunctional Attitudes Scale (DAS; Weissman \& Beck [56]), Positive And Negative Affect Scale-Expanded Form (PANAS-X; [57]) and Automatic Thoughts Questionnaire (ATQ: [45]). After testing the subjects, during a week, four times a day their mood and thoughts registered on a handheld computer. Six months after, the depressive symptoms were again measured and the participants completed a measure of negative life events: The College Student Life Events Schedule (Sandler $\&$ Lakey [58]). The results pointed out that cognitive reactivity remained predictive of follow-up depressive symtom scores $(\mathrm{p}<0.05)$ and accounted for $6.1 \%$ of the variance in follow-up depressive symptom. Dysfunctional atitudes were predictive of follow-up depressive symptom, controlling for initial depressive symptom $(\mathrm{p}=0.06)$ and account for $5.5 \%$ of the variance in folow-up depressive symptoms. Cognitive reactivity was somewhat more predictive of follow-up depressive symptom scores in participants who had experienced high levels of life stress. These results indicate that cognitive reactivity serves as a risk fator for the development of depressive symtoms. 
Shankman et al. [59] assessed if high negative emotionality (sadness, fear, anger) and low positive emotionality (anhedonia, lack of enthusiasm, lack of energy) in children are risk factors for developing depression. The sample of 329 pre-school children was observed in the laboratory in 12 sessions with selected episodes to mention relevant behaviors removed from Laboratory Temperament Assesssment Battery (LAB-TAB; [60]) and taxes on EEG were performed in specific environment. The results showed that both low positive emotionality and high negative emotionality are suficient for confering risk for depression. Using EEG asymmetry as a marker for depression, the direction of interaction suggests that children with low positive emotionality or high negative emotionality are at risk for depression and children with both temperamental traits are not a greater risk than those with only one. The authors indicated that these temperamental traits may be good targets for preventative strategies.

Catalino \& Fredrickson [14] investigated whether and how routine activity promote flourishing - a state of optimal mental health. The authors claim that flourishers experience greater positive emotional reactivity to pleasant events and buid more resources over time. To test how positive emotional reactivity in routine activities can promote mental health the authors recruited 208 subjects to during five consecutive weeks respond to The Day Reconstruction Method (DRM) on line and report a typical weekday. Before the participants respond to DRM, the group aswered to the following test: The Five Facet Mindfulness Questionnaire [61], The Beck Depression Inventory (BDI; [21]), Beck Anxiety Inventory (BAI; [62]), The Composite International Diagnostic Interview Short Form- Alcohol Dependence and Drug Dependence (CIDI-SF; [63]) and The Mental Health Continuum-Short Form [64]. The result of the testing and implementation of DRM enabled the group was classified as: flourishers (108), non florishers (67) and depressed (33). Three months after, the subjects who completed the DRM were invited to respond again to The Five Facet Mindfulness Questionnaire [61] in this stage the participants slipped to 178 subjects who was the final sample. Examinig the daily lives of florishers compared to depressed and non florishers the authors discovered that flourishers respond more positively to pleasant activities, ranging from interacting to learning. The analysis pointed out important differences in florishers individuals in positive emotionality that modify significantly the capabilities of coping and feeling of well being and that the maintenance of this blossoming is the importance given to ordinary everyday experiences as, for example, chat with a colleague, helping, interacting, playing, learning, spiritual activity and exercising.

Mauss et al. [6] investigated whether dissociation between positive emotion experience and behaviors predict two facets of psychological functioning- depressive symptoms and well-being- and if so, wether these effects are mediated by social connectedness. The study used a sample of 135 students and was conducted in three times. Initially there was a survey of levels of depression and well-being were assesed by a Five-item Short Version of The Center for Epidemiological Studies Depression Scale (CES-D; [28]), and The Five-item Satisfaction With Life Scale (SWLS; [39]). In a second moment, six months after, it was verified a positive excitement and dissociation of behavioral experience by a session where participants watched two minutes of amusing film clip and a laboratory software was used to compute averages for each second of data during the film. Six months after, social connectednnes, appraisal social support and belongingness social support were each assessed with Fouritem Scales from The Interpersonal Support Evaluation List [65], loneliness was assessed with the Eight-item UCLA Loneliness Scale [66]. The results showed that positive experience-behavior dissociation predicted social connectedness $(\mathrm{p}<0.05)$; social connectedness was negatively associated with depressive symptoms $(\mathrm{p}<0.05)$ and positively associated with well-being $(p<0.05)$. This study showed that the more participants' positive experience and behaviors were dissociated during a positive emotion induction, the greater levels of depressive symptoms and the lower levels of wellbeing participants experienced six months later.

In another study, [67] examined the psychological health correlates of positive emotion variability versus stability across 2 distinct studies. The first study used a daily experience approach in 244 adult participants from a U.S. community and they were asked to rate their positive feelings each day before going to bed for 14 consecutive days and indicated how "happy" and "excited" they felt over the past 24 hours on a scale ranging from 1 (very slight/not at all) to 5 (extremely) with combine responses into one positive emotion composite. The authors calculated two scores individually for each participant: positive emotion variation (PE var) as the standard deviation across 14 days and overall positive emotion (PE mean) as the average across 14 days. Participants also completed a self-report version of the Global Assessment of Functioning Scale (DSM-IV), Satisfaction With Life Scale [39], Beck Depression Inventory [21] and The Anxiety Screening Questionnaire [68]. The study 2 adopted a daily reconstruction method in 2391 French adult recruited through a large on line study. Participants were asked to report what they did on the previous day, episode by episode. For each episode participants indicated a positive emotion from The Differential Emotion Scale [69] and again the two scores were calculated the PEvar and the PEmean as the positive emotion average across episodes. The participants completed the Satisfaction With Life Scale [39] and Subjective Happiness Scale [70]. The results showed that the participants of the first study who experienced greater PEvar throughout the 14 day study period reported worse psychological health outcomes including decreased life satisfaction and functioning and increased depression and anxiety $(\mathrm{ps}<0.05)$. On the second study participants who reported greater PEvar throughout the previous day experienced worse psychological health outcomes with decreased life satisfaction, daily satisfaction and subjective happiness $(p<0.01)$. These findings support the notion that positive emotion variability plays an important role in psychological health above overall levels of happiness, and that too much variability might be maladaptative and might increase anxiety and depression.

\section{CASE-CONTROL STUDIES}

In the first case-control study, [12] examined whether there would be differences in perceptions of consensus for positive, negative and neutral events in depressive and non- 
depressive and the effects of these interpretations both on attributive style and on levels of depression. To this end, 52 subjects were divided according to The Beck Depression Scale (BDI; [21]). 23 subjects were classified as depressed, 22 subjects were classified as nondepressed and seven participants were classified neither depressed nor nondepressed. In this phase the subjects were divided into groups of five to ten participants and for an hour responded the following questionnaires in a booklet: The Beck Depression Scale (BDI; [21]), The Attributional Style Questionnaire (ASQ; [71]) and a event questionnaire contained 45 statements written in second person that described positive, negative and neutral interpersonal and achievement events. The results indicated that positive events were rated as having happened more often than negative or neutral $(\mathrm{p}<0.0001)$. A main effect of target across all event types suggested that the events were rated as happening more to others than to itself $(\mathrm{p}<0.0001)$, an interaction between target and depression indicated that this pattern was truer for depressed participants than nondepressed $(\mathrm{p}<0.01)$ and an interaction between event type and target in nondepressed subjects, indicated that positive events were rated as more likely to happen to itself than to others, whereas negative and neutral events were rated as more often to happen to others than to the self $(p<0.0001)$. The depression is not affected by the perception of others but by the perceptions of the self that have a direct association with depression and an effect mediated through attributional style for negative events. The authors pointed out the importance for the development of prevention and treatment strategies to determinate the causes of a depressive attributional style.

Sheeber et al. [5] focused on delineating the dimensions of affective experience in depressive disorder in adolescents. The affect regulation involved in initiating, maintaining and moduling the occurence, intensity and duration of the experience. The affective behaviors of 75 adolescents with major depression were compared to a matched cohort of 77 healty adolescents and the participants were submitted for these tests: The Center for Epidemiological Studies- Depression Scale (CES-D; [28]), The Diagnostic Interview Kiddie-Sads Trace (K-SADS) [72], The_Positive and Negative Affect Scale-Expanded Version (PANAS-X; Watson \& Clark [57]), The Meta Emotion Interviews (MEI/CHILD-MEI; [73]) and Behavioral Observations: The Living in Family Environments System (LIFE; [74]). The results showed that depressed boys and girls showed relative duration of dysphoric and angry affect, in particular, depressed boys and girls remained in angry states longer $(p<0.01)$ and depressed girls also remained in dysphoric states longer, than did their healthy peers. The depressed adolescents didn't maintain happy affective states for as long a time as the healthy ones $(p<0.01)$. The authors highlight the deficit of maintenance of positive affect and the longer duration of physiological responses associated with negative affect as a critical mechanism in depression.

In the last case-control study [7] examined whether depressed participants were also impaired at selecting relevant positive content in the context of representations in working memory (WM) such an impairment would limit depressed person's ability to use positive material to ameliorate the cognitive effects of negative information. The authors re- cruited 42 subjects and according to The Structured Clinical Interview for the DSM-IV (SCID [75]) divided in 20 depressed and 22 healthy and administered Emotion Regencyprobes task based on research by Monsell [76] with positive words, neutral and negative content where 260 words with emotional content and 330 neutral words from the Affective Norms for English Words (ANEW; [77]). The results presented that for the nondepressed participants, interferences levels differed significantly across conditions $(p<0.001)$ and this participants exhibited lower levels of interference in the emotion focus condition in the neutral and the emotion nonfocus conditions $(p<0.001)$. For the depressed group levels did not differ across conditions $(p>0.05)$ and these participants exhibited higher interference levels than did their nondepressed peers in the emotion focus condition $(\mathrm{p}<0.01)$. Nondepressed participants showed less interference for positive than for neutral information and depressed subjects showed equivalent levels of interference for positive and neutral stimuli.

\section{RANDOMIZED CLINICAL TRIALS}

Beck \& Strong [78] investigated the effects of positive and negative connotation of the speech therapist about the symptoms of depression. The aim of the study was to compare the results of different interpretations of therapists to stimulate changes in depressed patients. For that, 84 students responded to the Beck Depression Inventory [21] and the 30 who had scores between eight and 31 were selected for the study (moderately depressed). The participants were divided into three groups of 10 where a group participated in two interviews with positive interpretations, the other group had two interviews with negative interpretations and the trird group was the control and the two sessions only answered BDI Scale, Personal Mood Inventory 「79\ and BarrettLennard's Relationship Inventory [80]. A month after the second interview all students were contacted again and retested in two sessions. At the end of the first interview of the posttest the therapist assigned students a task to perform every day until the next interview, such as walking in a park and greeting a stranger, visiting a friend, or going to the Student Union and saying hello to someone. The difference between the control group and the groups that received intervention was statistically significant $(p<0,005)$. From the 20 subjects who participated in the interviews 16 reported in posttest that suffering had declined or disappeared. The group that received positive interpretations, nine students responded that the mood was no longer a problem for them while five students of the group that received negative interpretation reported that their mood continued to be a problem that causes suffering. This study identifies the interpretation with positive connotation as a therapeutic method facilitator of change to the depression.

Joormann et al. [81] examined whether depressive patients could intentionally forget negative material. 72 volunteers were divided between depressive and non-depressive according to DSM IV Structured Clinical Interview (SCID [75]) and responded to the Beck Depression Scale II (BDI-II; [40])(the average score for the 36 subject of control group was 1.8 and the average for the depressive group 36 was 27.5). The first phase was the learnig moment and 36 words negative content, neutral 36 positive and 36 were selected 
from the Battery of English Words of Affective Contents [77] (ANEW: 1999) and were paired to be presented to the participants and be memorized. The sessions lasted from 60 to 90 minutes and the first phase was to learn where 43 pairs of words were presented on the computer screen for five seconds each. The participants were instructed to study the words for later testing. At the end of this phase, the subjects were tested and needed to get $50 \%$ correct to follow for next step. The participants that do not achieve the goal answered to the Beck Depression Scale II (BDI-II; [40]) tests and Strategies Questionnaire and not progressed.

In the second phase, the participants were instructed not to think in the words that appeared on the computer in red and to answer and memorize the words that appear in green. Half of the participants were asked to suppress positive words and negative answer and the other half the other way around. In the third phase, the subjects were instructed to remember all the words of the learning phase and the words deleted and remembered and in this stage each word appeared in black by four seconds on the computer. The group without depression presented a percentage of $84 \%$ for remembrance of positive words deleted and reinforced negative versus $83 \%$ for the reverse situation. The depressive group presented $85 \%$ for recalling words that suppressed the positive content and reinforced the negative against $73 \%$ for remembrance that suppressing the negative content words and stressed the positive. The study showed that depressive participants managed to intentionally forget negative words content and suggests that this training can become a strategy able to combat negative thoughts of depressive rumination.

Seligman et al. [3] have developed research in order to prove the effectiveness of positive psychology interventions to increase happiness. The survey was conducted online and the authors prescribed five exercises to increase happiness and a placebo control. An exercise focused on developing gratitude (write a letter of gratitude and delivering it to someone important), two focused on developing talents and strengths (identifying personal strengths and using their strengths in different ways), two emphasized making patients what was good in them (you at its best - they reported a time where they were happy and what forces were at that time and three good things in life where they described three situations that were good on the day and causes). The placebo group was writing exercise for a week about recent memories. In this sense, 577 participants were recruited on line in a month and completed two questionnaries, The Center for Epidemiological Studies-Depression Scale (CES-D; [28]) and The Steen Happiness Index (SHI; [3]). The subject visited a specific Web site where they were encouraged to print the instructions and perform the same exercises during a week and then return to the Web site to completed follow-up questionnaires in one week, one month, three months and six months and answered the same measures of happiness and depression. Only 411 subjects completed the five follow-ups and were considered statistically. The results showed that two of the exercises (using their personal strengths and three good things in life) increased levels of happiness and depression symptoms decreased for six months. The exercise of gratitude visit generated positive changes for a month and the other two exercises and the placebo showed transient effects on levels of happiness and depressive symptoms.
Research has shown that exercises that emphasize personal and positive emotion forces immediate effect by increasing the levels of happiness and reducing depressive symptoms.

In another study, [16] produced two surveys in order to prove the effectiveness of positive psychotherapy, one with medium to moderately depressed adults and another with severely depressed adults. The first study described 40 moderately depressed subjects with scores between 10 and 24 on the Beck Depression Inventory-II (BDI-II; [40]) were recruited. Nineteen participants were submitted to positive psychotherapy, 21 of the control group were not submitted to psychotherapy. The treatment lasted six weeks with sessions of two hours duration. Both groups were tested soon after the intervention, three months, six months and one year after the intervention with the following instruments: The Beck Depression Scale II (BDI-II; [40]) and The Satisfaction With Life Scale (SWLS; 1985).

Participants who have undergone positive psychotherapy showed decrease of depressive symptoms and increased satisfaction with life during the intervention and this result is sustained over time. In the second survey reported by the authors, 32 severely depressed subjects were allocated in three modes of intervention in order to analyze its effects. Eleven have undergone positive psychotherapy with only 14 sessions following the protocol proposed by the authors. Nine were subjected to the usual psychotherapy treatment depression and were attended by five psychologists and a last group of 12 individuals in addition to the usual psychotherapeutic treatment made use of antidepressants. After the interventions the participants were subjected to the following tests: Hamilton Rating Scale for Depression (HRSD; [82]); Zung Self-Rating Scale (ZSRS; [83]); Outcome Questionnarie (OQ; [84]); The Satisfaction With Life Scale (SWLS; [39]) and were assessed for the remission of depression symptoms. The results indicated that the positive psychotherapy performed better than the others with margin calls results in all instruments. In PPT group ZSRS presented 43.27 score against 54.67 from usual treatment and 55.70 from usual treatment plus medication. In Outcome Questionnaire, the PPT group scored 45.82 versus 63.67 and 55.50. And in the SWLS, the score was 21.91 against 19 and 18.50, increasing the positive emotion, engagement, meaning and significantly, reducing the levels and depression symptoms.

Fredrickson et al. [85] conducted a survey in order to investigate the effects of loveling-kindness meditation on health and well-being. The 139 subjects were divided between 67 that initially would receive training in meditation and 72 that would be initially from the control group. For nine weeks, all participants were instructed to practice this meditation and to access a Web site in order to complete the following questionnaires: Mindfulness and Awareness Scale [86]; Hope Scale [38]; Savoring Beliefs Inventory [87]; Life Orientation Test LOT: [88]; Ego-Resilience Measure [35]; Psychological Well-Being Scale [31]; Dyadic Adjustment Scale [89]; Positive Relations With Others, [90]; Satisfaction With Life Scale [39] and Center for Epidemiological Studies - Depression Measure CES-D; [28]. After a week of response to the questionnaires the group of 67 subjects participated in a workshop with daily practice of meditation and every day the subjects visited the Web site and reported their 
emotions and the time spent with meditation the day before and completed the Modified Differential Emotions Scale (mDES; [91]) on-line monitoring continued for another week after the workshop ended. At the end the participants completed the same instruments as a posttest. Two months after, the meditation workshop began to the control group of 72 subjects, but there were no further measurement. The study showed that participants who invested an hour per week practicing meditation significantly increased their positive emotions in everyday situations of life, their social interactions and their personal resources and reduced their symptoms of depression.

Huta \& Hawley [92] conducted two surveys with healthy individuals and depressive to verify the role of personal strengths and vulnerabilities in well-being. In the first study 241 healthy participants attended search on line where the focus was to analyze the influence of positive well-being about the negative affect and depression. Subjects completed a survey on line and then answered to the following inventories: Values in Action Inventory of Strengths (VIA-IS; Peterson \& Seligman [93]); Dysfunctional Attitudes Scale DAS; [56]; Beck Depression Inventory Second Edition BDI-II; [40]; Satisfaction With Life Scale SWLS; [39]; Positive Affect and Negative Affect [94]; Self-Esteem [95]; Subjective Vitality Scale [96]; Meaning [97] and Elevating Experience, [97]. The results pointed an interaction between strengths and vulnerabilities and suggest that personal forces protect people against harmful effects of vulnerabilities. The second study reported in the article presented 54 depressive individuals, with a minimum score of 14 in the Beck Depression Scale II (BDI-II; [40]), which were submitted to cognitivebehavioral protocol of the book the Mind over mood: change how you feel by changing the way you think [98] before and after respond to the survey with the instruments previously reported on the first study of the article. The focus of the second study was to analyze the relationship between forces and vulnerabilities in depressed. The results reinforce personal forces have main role in reducing depressive symptoms and points out that three forces in particular promoted the recovery of depression: hope, appreciation to the beautiful and excellence and spirituality.

Bylsma et al. [99] evaluated the emotional reactivity to daily events in depressive and healthy subjects. 99 participants after answering the Structured Clinical Interview for DSM IV-TR Axis I Disorders (SCID-I) were divided into three groups: 35 with major depression, 26 with minor depression and 38 healthy and they were submitted to Computerized Experience-Sampling-Method (ESM; [100]). For three consecutive days the subjects recorded in a handheld computer programmed to sound an alarm 10 times during the day (between 8 a.m. and 11 p.m.) to the individual account of humor and the context and nature of the most important emotional events that had occurred since the last record. After the three days of ESM logs the handheld was returned and the Day Reconstruction Method (DRM; [100]) was answered. DRM requested participants to rebuild the previous day structuring it as a continuous series of episodes describing details such as what they were doing, time of episodes, and thoughts and feelings involved. While the subjects submitted to DRM they answered Beck Depression Inventory-II (BDI-II; [40]); and The Beck Anxiety Inventory (BAI; [62]).
The results showed that the depressives subjects report their failures, highest rates of negative affect and negative social interactions while healthy participants report their successes, positive affection and positive social interactions and that the depression participants are also more reactive nicely to daily events that healthy ones.

Albarracin \& Hart [101] reported four experiments that examined the relationship between action, inaction and humor. In the first experiment, 87 psychology students were induced to experience happiness and anger and wrote a letter to a friend about a personal living experienced happiness, frustration or anger. Participants who would try neutral mood were asked to write about a typical day in their lives. Five minutes after that, completed sentences with 20 neutral, positive and negative words that connoted both action (motivation, make, behavior, engaged, action, do, go and active) and inaction (still, pause, interruption, calm, cripple, unable to stop and freeze). The task is part of the Computerized Edinburg Associative Thesaurus [102]. Shortly after, the subjects completed 21 issues accessing verbal ability (antonyms, complete sentences and analogies) and mathematical ability (resolution of problems and algebraic equations). The results showed that participants in positive mood and neutral conditions showed better performance in terms of action while the negative mood showed conditions for inaction.

In the second experiment, 139 participants completed the same sentences with words of neutral content (button, cement, chair, lock, pencil, carpet and paper), and the humor was also induced to happiness and anger. Shortly after the subject participated in a decision test where a story was received to be read ("Mr. Miller"; [103] and after reading this material were asked to choose between 12 titles of articles that were relevant to reaching a decision. The numbers of articles that the subjects read were taken into account and the result showed that the design of action increased the selection of articles on subjects who have experienced positive mood and that it decreased in participants who experienced negative mood. In the third experiment, a sample of 81 participants were induced to experience happiness and anger and soon after the organizing and completing scrambled sentences using words of inaction (first experiment) and neutral words (second experiment). On the next moment they received a celebrity photo for review and then they answered questions about what the recall from the image. The results also revealed an association with positive humor and action and negative mood with inaction influencing on memory performance. The experiment four replied the first with 140 students of Psychology except that negative mood induced was the sadness instead of anger. The four experiments that reinforced the negative affect thwart the activity and increase the inaction while the positive affect enhance and reinforce the action as well as the performance.

Dalgleish et al. [104] recruited 50 volunteers who completed the Structured Clinical Interview for the DSM-IV Axis I were divided into 16 depressed, 17 remitted depression at least for three months and 17 never depressed in order to verify the structure of life. A week later the subjects were submitted to Life-Structure Card-Sorting Task proposed by Zajonc and adapted by Linville [105] where they were asked to divide their lives into chapters and instructed 
to write their story using the words set out in 46 cards both for the past and for the future. Immediately after that they answered to the following tests: Beck Depression Inventory (BDI; [40]), the Spielberger State-Trait Anxiety Inventory (STAI; [20]) and Positive Affect Negative Affect Scale (PANAS; [94]). The data showed a depressive profile relative to the past with predominance of negative information and vulnerability in depressive group and in participants at remission, but surprisingly the groups showed no significant differences in ratings of life structure for the future. This research points out that even with a history of depression peolpe can contemplate the future not as a mere projection of the past.

\section{DISCUSSION}

In this study we aimed to conduct a systematic review of the literature on the impact of positive emotion in the treatment of depression and on the use of strategies of positive psychology that involves positive emotion to treat and reduce symptoms of depression. It has been observed through the studies, $[3,16,85,8,11,92,10,14]$ that strategies of positive psychology have impact on signs and symptoms of depression, as well as seeming to prevent and increase wellbeing, producing protective elements, such as resilience and coping capabilities that reduce relapses in the treatment of depression. The positive emotion and the relations with depression and well being was observed through the studies [9, $23,12,49,13,5,15,55,67,59,6]$.

The positive psychology, according to Wood \& Tarrier [2] introduced a new form of treatment which puts in evidence the study of virtuous aspects of human nature in addition to developing personal forces believing that the same work as protectors against the disease. In this context [17], the positive psychology is the science of qualities and resilience.

Based on the analysis of selected studies on depression and positive psychology as certain a vast repertoire of strategies in order to increase the positive emotion and promote cognitive opening necessary for the treatment. A lot of strategies were used successfully, we emphasize the pleasant activities as religious service, watching movies, playing cards, eating out, gardening [23, 41], mindfulness [85, 14], meditation [85], gratitude [8], the development of positive cognitions through the restructuring of negative content thoughts [7], changing the style of thinking from pessimist to the optimist $[12,11,10]$ ), social connectivity [6], developing talents and strengths to increase coping strategies $[3,85,8])$, expanding social support network in order to develop resilience and well-being, positive emotion, engagement, achievement, and positive relationships $([13,8,11,14,6$, $10]$.

All the techniques used in the surveys $[11,2,10,7,78$, 92] aim to reduce vulnerabilities, enhance personal forces and resources to lessen the impact and therefore the losses generated by depression and thus develop resilience and well-being.

In $[33,10,11,55,12,101]$ stressed the importance of positive social relationships support generators as support for the development of resilience and reducing the levels of stress and depression, indicating therapeutic possibilities to strengthen social support network.

The positive cognitive triad (positive view of yourself, of the world and of the future), automatic positive thoughts and optimistic were highlighted by Crocker, [10-12] as generators of satisfaction, resiliency and reducing levels of depression. In this context, psychologists must develop strategies in order to teach their depressive patients the importance of the development of positive cognitive triad, and optimistic style of automatic thoughts positive. According to Dalgleish et al., [104] it was observed that individuals with a history of depression and with negative information and vulnerability in the life on the past and on present, surprisingly managed to contemplate the future not only as a mere projection of the past. This finding challenges the literature that claims that the negativity and hopelessness are present on the vision of future of depressive and brings the possibility of therapeutic intervention in this cognitive aspect.

The behavioral aspect is also reviewed $[23,85]$ that emphasize the role of pleasant activities in order to reduce the intensity of the depression, through the engagement in pleasant activities to minimize depression and produce wellbeing.

Another fundamental aspect of positive psychology is to develop personal forces like: talents, strengths and abilities in patients with much vulnerability, because these personal forces are protective elements and produce well-being $[18,10,78,92]$ allege that the forces have key role in reducing depressive symptoms and demonstrated in their research that three forces: the hope, the appreciation of the beautiful and excellence and spirituality, promoted depression recovery despite cognitive vulnerabilities submitted by individuals.

It was observed $[9,19,49,11,14,10,3,16,85,92,6$, 67] that the development of positive emotion has led to a better psychological functioning and consequently a reduction of symptoms of depression.

A limitation of the study, however, lies in the fact that most articles have produced qualitative results showing the improvement of patients in behavioral terms. It would be interesting that new studies focus on production of quantitative data with statistical treatment.

\section{CONCLUSION}

On the basis of selected articles it was established that the strategies of positive psychology are potentially effective tools for the prophylaxis and treatment of depression. The positive emotion, in fact figured in many strategies used in the presented research $[9,19,49,11,14,10,3,16,85,92,6$, 67] and is directly related to the improvement of the levels of depression. Increasing positive emotion, developing personal forces, seeking direction, meaning and engagement for the daily patient proved to be important and meaningful strategies for reducing the signs and symptoms and relapse, so applicants in depression [78, 18, 10, 6, 14].

The applicability of the findings of this study is characterized by a range of strategies which are important therapeutic procedures for reduction levels of depression. However, the use of a repertoire of differentiated strategies hindered a comparative analysis of the effectiveness of treatments and 
the accession and evasion of it. In this sense, it would be interesting more researches to be carried out using a limited number of strategies, this way comparative analysis can be performed.

\section{CONFLICT OF INTEREST}

The authors confirm that this article content has no conflicts of interest.

\section{ACKNOWLEDGEMENTS}

Declared none.

\section{REFERENCES}

[1] Seligman MEP. Building human strength: psychology's forgotten mission. Am Psychol 1998; 29.

[2] Wood AM, Tarrier N. Positive Clinical Psychology: A new vision and strategy for integrated research and practice. Clin Psychol Rev 2010; 30: 819-29.

[3] Seligman MEP, Steen TA, Park N, Peterson C. Positive psychology progress: Empirical validation of interventions. Am Psychol 2005; 60: 410-21.

[4] Sin NL, Lyubormirsky S. Enhancing well-being and alleviating depressive symptoms with positive psychology interventions: A pratice-friendly meta-analysis. J Clin Psychol 2009; 65: 467-87.

[5] Sheeber LB, Allen NB, Leve C, Davis B, Shortt JW, Katz LF. Dynamics of affective experience and behavior in depressed adolescents. J Child Psychol Psychiat 2009; 50: 1419-27.

[6] Mauss IR, Shallcross AJ, Troy AS, et al. Don't Hide Your Happiness! Positive emotion dissociation, social connectedness, and psychological functioning. J Pers Soc Psychol 2011; 100: 738-748.

[7] Levens SM, Gotlib IH. Impaired selection of relevant positive information in depression. Depress Anxiety 2009; 26: 403-10.

[8] Wood AM, Maltby J, Gillett R, Linley PA, Joseph S. The role of gratitude in the development of social support, stress, and depression: Two longitudinal studies. J Res Pers 2008; 42: 854-71.

[9] Lightsey OR. "Thinking Positive" as a Stress Buffer: The role of positive automatic cognitions in depression and happiness. J Counsel Psychol 1994; 41: 325-34.

[10] Mak WWS, Ng ISW, Wong CCY. Resilience: Enhancing wellbeing through the positive cognitive triad. J Counsel Psychol 2011; 58: 610-7.

[11] Sawyer MG, Pfeiffer S, Spence SH. Life events, coping and depressive symptoms among young adolescents. A one - year prospective study. J Affect Disorders 2009; 117: 48-54.

[12] Crocker J, Alloy LB, Kayne NT. Attributional Style, depression, and perceptions of consensus for events. J Pers Soc Psychol 1988; 54: $840-6$

[13] Dowrick C, Kokanovic R, Hegarty K, Griffiths F, Gunn J. Resilience and depression: Perspectives from primary care. Health 2008; 12: 439- 52.

[14] Catalino LI, Fredrickson BL. A tuesday in the life of a flourisher: The role of positive emotional reactivity in optimal mental health. Emotion 2011; 11: 938-50.

[15] Liu Q, Shono M, Kitamura T. Psychological well-being, depression, and anxiety in japanese university students. Depress Anxiety 2009; 26: 99-105.

[16] Seligman MEP, Rashid T, Parks AC. Positive psychotherapy. Am Psychol 2006; 61: 774-88

[17] Seligman MEP, Parks AC, Steen T. A balanced psychology and a full life. Philos Trans R 2004; 359: 1379-81.

[18] Bradley BP, Mogg K. Mood and Personality in Recall of Positive and Negative Information. Behav Res Ther 1994; 32: 137-41.

[19] McNair DM, Lorr M, Droppleman LF. Profile of mood states. San Diego, CA: Educational and Industrial Testing Service 1971.

[20] Spielberger CD, Gorsuch RL, Luschene R, Vagg PR, Jacobs GA. Manual for the State- Trait Anxiety Inventory (Form Y): SelfEvaluation Questionnaire. Palo Alto. CA: Consulting Psychologists Press 1983.

[21] Beck AT, Ward CH, Mendelson M, Mock J, Erbaugh J. An inventory for measuring depression. Arch Gener Psychiat 1961; 4: 56171 .
[22] Eysenck SBG, Eysenck HJ. Manual of the EPQ (Eysenck Personality Questionnaire). London: Holdder \& Stoughton 1975.

[23] Lawton MP, Winter L, Kleban MH, Ruckdeschel K. Affect and quality of life. J Aging Health 1999; 11: 169-98.

[24] Lawton MP, Moss M, Fulcomer M, Kleban MH. A research and service oriented Multilevel Assessment Instrument. J Gerontol 1982; 37: 91-9.

[25] Joreskog KG, Sorbom D. LISREL 7. User's reference guide. Mooresville, IN: Scientific Software 1989.

[26] Mc Cullough ME, Emmons RA, Tsang JA. The grateful disposition: A conceptual and empirical topography. J Pers Soc Psychol 2002; 82: 112-27.

[27] Cohen S, Hoberman H. Positive events and social supports as buffers of life change stress. J Appl Soc Psychol 1983; 13: 99-125.

[28] Radloff LS. The CES-D scale: A self-report depression scale for research in the general population. Appl Psychol Measur 1977; 1: 385-401.

[29] Cohen S, Williamson G. Perceived stress in a probability sample of the United States. In: Spacapam S, Oskamp S Eds., The Social Psychology of Health. Newbury Park, CA: Sage 1988

[30] John OP, Srivastava S. The big five trait taxonomy: History, measurement, and theorical perspectives. In: Pervin L.A. \& John O.P. Eds. Handbook of personality: Theory and research. second ed. pp. 102-138. New York. NY: Guilford Press 1999.

[31] Ryff CD, Singer B. Psychologycal well-being: meaning, measurement, and implications for psychotherapy research. Psychot Psychosom 1996; 65: 14-23.

[32] Zigmond AS, Snaith RP. The hospital anxiety and depression scale. Acta Psychiatr Scand 1983; 67: 361-70.

[33] Vranceanu Ana-Maria, Gallo LC, Bogart LM. Depressive symptoms and momentary affect: The role of social interaction variables Depress Anxiety 2009; 26: 464-70.

[34] Wheeler L, Reis HT. Self-recording of everday life events; origins, types and uses. J Pers 1991; 59: 339-54

[35] Block J, Kremen AM. IQ and ego-resilience: Conceptual and empirical connections and separateness. J Pers Soc Psychol 1996; 70: 349-61.

[36] Rosemberg M. Society and the adolescent self-image. Princeton, NJ: Princeton University Press 1965.

[37] Beckman EE, Leber WR, Watkins JT, Boyer JL, Cook JB. Development of an instrument to measure Beck's cognitive triad: The cognitive triad inventory. J Consult Clin Psychol 1986; 54: 566-7.

[38] Snyder CR, Sympson SC, Ybasco FC, Borders TF, Babyak MA, Higgins RL. Development and validation of the State Hope Scale. J Pers Soc Psychol 1996; 70: 321-35.

[39] Diener E, Emmons RA, Larsen RJ, Griffin S. The Satisfaction With Life Scale. J Pers Assess 1985; 49: 71-5.

[40] Beck AT, Brown G, Steer RA. Beck depression inventory manual. $2^{\text {nd }}$ ed. San Antonio, TX: Psychological Corporation 1996.

[41] Lewinsohn PM, Libet J. Pleasant events, schedules, and depressions. J Abnormal Psychol 1972; 79: 291-5.

[42] MacPhillamy D, Lewinsohn PM. The pleasant events schedule. Eugene: University of Oregon 1971

[43] Lubin G. Adjective checklists for the measurement of depression. Arch Gener Psychiat 1965; 17: 183-6.

[44] Ingram RE, Wisnicki KS. Assessment of positive automatic cognition. J Cousel Clin Psychol 1988; 56: 898-902.

[45] Hollon SD, Kendall PC. Cognitive self-statements in depression: Development of an automatic thoughts questionnaire. Cognit Ther Res 1980; 4: 383-395.

[46] Sarason IG, Johnson JH, Siegel JM. Assessing the impact of life changes: Development of the life experiences survey. J Cousel Clin Psychol 1978; 46: 932-946.

[47] Kanner AD, Coyne JC, Schaefer C, Lazarus RS. Comparison of two models of stress measurement: Daily hasless and uplifts versus major life events. J Behav Med 1981; 4: 1-39.

[48] Fordyce MW. A review of research on the Happiness Measures: A sixty second index of happiness and mental health. Soc Indicat Res 1988; 20: 355-81.

[49] Nezlek JB, Kuppens P. Regulating positive and negative emotions in daily life. J Pers 2008; 76: 561-80.

[50] Gross JJ, John OP. Individual differences in two emotion regulation processes: Implications for affect, relationships, and wellbeing. J Pers Soc Psychol 2003; 85: 348-62. 
[51] Brugha TS, Cragg D. The list of threatening experiences: the reliability and validity of a brief life events questionnaire. Acta Psychiatry Scand 1990; 82: 77-81.

[52] D'Zurilla TJ, Nezu AM, Maydeu-Olivares A. Social ProblemSolving Inventory- Revised (SPSI-R). Multi-Health Systems Inc., North Tona-wanda, NY 2002.

[53] Causey DL, Dubow EF. Development of a self-report coping measure for elementary school children. J Clin Child Psychol 1992; 21: 47-59.

[54] Beyondblue. (2007). Beyondblue Schools Research Initiative. July 19. Retrieved January 31, 2008, from http://www.beyondblue.org.au/.

[55] Wenze SJ, Gunthert KC, Forand NR. Cognitive reactivity in everday life as a prospective predictor of depressive symptoms. Cognitive Ther Res 2010; 34: 554-62.

[56] Weissman A, Beck AT. Development and validation of the Dysfunctional Attitude Scale: A preliminary investigation. Paper presented at the annual meeting of the Education Research Association, Toronto, ON: Canada 1978.

[57] Watson D, Clark LA. The PANAS-X: Manual for the positive and negative affect schedule- expanded form. Unpublished Manuscript. Iowa City: University of Iowa 1994.

[58] Sandler I, Lakey B. Locus of control as a stress moderator: The role of control perceptions and social support. Amer J Commun Psychol 1982; 10: 65-78.

[59] Shankman SA, Klein DN, Torpey DC. Do positive and negative temperament traits interact in predicting risk for depression? A resting EEG study of 329 preschoolers. Dev Psychopathol 2011; 23: 551-62.

[60] Goldsmith HH, Reilly J, Lemery KS, Longley S, Prescott A. Laboratory Temperamental Assessment Battery: Preschool version. Unpublished version 1995

[61] Baer RA, Smith GT, Hopkins J, Krietemeyer J, Toney L. Using self-report assessment methods to explore facets of mindfulness. J Pers Assess 2006; 13: 27-45.

[62] Beck AT, Epstein N, Brown G, Steer RA. An inventory for measuring clinical anxiety: Psychometric properties. J Consult Clin Psychol 1988; 56: 893-7.

[63] Walters EE, Kessler RC, Nelson CB, Mroczek D. Scoring the World Health Organization's Composite International Diagnostic Interview Short Form (CIDI-SF). Revised December 2002. Retrieved from: http://www3who.int/cidi/CIDISFScoringMemo1203-02.pdf. Acessed January 15, 2007.

[64] Keyes CLM. Brief description of the mental health continuum short form (MHC-SF). Retrieved from http://www.sociology.emory.edu/ckeyes/. 2009. On line, retrieved January 15, 2010

[65] Cohen S, Hoberman H. Positive events and social connectedness as buffers of life change stress. J Appl Soc Psychol 1983; 13: 99-125.

[66] Russell D. The UCLA Loneliness Scale (Version3): Reliability, validity and factor structure. J Pers Assessment 1996; 66: 20-40.

[67] Gruber J, Kogan A, Quoidbach J, Mauss IB. Happiness is best kept stable: Positive Emotion variability is associated with poorer psychological health. Emotion 2013; 13: 1-6.

[68] Wittchen HU, Boyer P. Screening for anxiety disorders: Sensitivity and specificity of the Anxiety Screening Questionnaire (ASQ-15). British J Psychiat 1998; 173 (Suppl. 34): 10-7.

[69] Izard CE. Patterns of emotions. New York: Academic 1972.

[70] Lyubomirsky S, Lepper HS. A measure of subjective happiness: Preliminary reliability and construct validation. Soc Indicat Res 1999; 46: 137-55.

[71] Seligman ME, Abramson LY, Semmel A, Von Baeyer C. Depressive attributional style. J Abnorm Psychol 1979; 88: 242-7.

[72] Orvaschel H, Puig-Antich J. Schedule for Affective Disorder and Schizofrenia for School-Age Children: Epidemiological Version. Unpublished manual 1994.

[73] Katz LF, Gottman JM. The Meta-Emotion Interview. University of Washington, Seattle, WA98195 1986.

[74] Hops H, Biglan A, Tolman A, Arthur J, Longoria N. Living in Familiy Environments (LIFE) coding system: Manual for codes (Revised). Eugene, OR: Oregon Research Institute 1995.

[75] First MB, Spitzer RL, Gibson M, Williams JBW. Structured Clinical Interview for DSM-IV Axis I Disorders-Clinican Version (SCID-CV). Washington, DC: American Psychiatry Press 1996.

[76] Monsell S. Recency, immediate recognition memory, and reaction time. Cogn Psychol 1978; 10: 465-501.
[77] Bradley MM, Lang PJ. Affective Norms for English words(ANEW): Technical Manual and affective Ratings. Gainesville FL: The center for research in psychophysiology, University of Florida 1999.

[78] Beck JT, Strong SR. Stimulating Therapeutic Change with Interpretations: A comparison of positive and negative connotation. J Counsel Psychol 1982; 29: 551-9.

[79] Strong SR. Emerging integrations of clinical and social psychology: A clinician's perspective. In G. Weary \& H. Mirles (Eds.), emerging integrations of clinical and social psychology. New York: Oxford University Press 1982.

[80] Barrett-Leonard G. Dimensions of therapist response as causal factors in therapeutic change. Psychological Monographs, 76(43, Whole N562) 1962.

[81] Joormann J, Hertel PT, Brozovich F, Gotib IH. Remembering the good, forgetting the bad: Intentional forgetting of emotional material in depression. J Abnorm Psychol 2005; 114: 640-8.

[82] Hamilton M. A rating scale for depression. J Neurology, Neurosurgery, and Psychiat 1960; 23: 56-62.

[83] Zung WWK. A self-rating depression scale. Arch Gener Psychiat 1965; 12: 63-70.

[84] Lambert MJ, Hansen NB, Umphress V, et al. Administration and scoring manual for the Outcome Questionnaire (OQ-45.2). Stevenson, MD: American Professional Credentialing Services 1996.

[85] Fredrickson BL, Cohn MA, Coffey KA, Pek J, Finkel SM. Open Hearts Build Lives: Positive Emotions, Induced Through LovingKindness Meditation, Build Consequential Personal Resources. J Pers Soc Psychol 2008; 95: 1045-62.

[86] Brown KW, Ryan RM. The benefits of being present: Mindfulness and its role in psychological well-being. J Pers Soc Psychol 2003; 84: 822-48.

[87] Bryant FB. A scale for measuring beliefs about savoring. J Mental Health 2003; 12: 175-96.

[88] Scheier MF, Carver CS, Bridges MW. Distinguishing optimism from neuroticism (and trait anxiety, self-mastery, and self-esteem): A re-evaluation of the Life Orientation Test. J Pers Soc Psychol 1994; 67: 1063-78.

[89] Spainer GB. Measuring dyadic adjustment: New scales for assessing the quality of marriage and similar dyads. J Marriage Family 1976; 38: 15-28.

[90] Ryff C. Happiness is everthing, or is it? Explorations on the meaning of psychological well-being. J Pers Soc Psychol1989; 57: 106981 .

[91] Fredrickson BL, Tugade MM, Waugh CE, Larkin G. What good are positive emotions in crises? A prospective study of resilience and emotions following the terrorist attacks on the United States on September $11^{\text {th }}, 2001$. J Pers Soc Psychol 2003; 84: 365-76.

[92] Huta V, Hawley L. Psychological Strengths and Cognitive Vulnerabilities: Are They Two Ends of the Same Continuum or Do They Have Independent Relationships with Well-being and Ill-being? J Happiness Stud 2010; 11: 71-93.

[93] Peterson C, Seligman MEP. VIA Inventory of Strengths (VIA-IS) 2001.

[94] Diener E, Emmons RA. The independence of positive and negative affect. J Pers Soc Psychol 1984; 47: 1105-17.

[95] Robins RW, Hendin HM, Trzesniewski KH. Measuring global selfesteem: Construct validation of a single-item measure and the Rosemberg Self-Esteem Scale. Pers Soc Psychol Bull 2001; 27: 151-61.

[96] Bostic TJ, Rubio DM, Hood M. A validation of the subjective vitality scale using structural equation modeling. Soc Indicat Res 2000; 52: 313-24.

[97] Huta VM, Grouzet F. Well-being predictors of eudaimonia and hedonia: A longitudinal study. Unpublished manuscript 2008

[98] Greenberger D, Padesky CA. Mind over mood: A cognitive therapy treatment manual for clients. New York, NY, USA: Guilford Press 1995.

[99] Bylsma LM, Taylor-Clift A, Rottenberg J. Emotional reactivity to Daily Events in Major and Minor Depression. J Abnorm Psychol 2011; 120 155-67.

[100] Kahneman D, Krueger AB, Schkade DA, Schwartz N, Stone AA. A survey method for characterizing daily life experience: The Day Reconstruction Method. Science 2004; 306: 1776-80.

[101] Albarracin D, Hart W. Positive Mood + Action = Negative Mood + Inaction: Effects of general action and inaction concepts on deci- 
sions and performance as a function of affect. Emotion 2011; 11: 951-7.

[102] Kiss GR, Armstrong C, Milroy R, Piper J. An Associative thesaurus of English and its computer analysis. In: Aitken AJ, Bailey RW, Hamilton-Smith N.(Eds.), The computer and literary studies (pp.153-65). Edinburg University Press 1973.
[103] Frey D. Reversible and irreversible decisions: Preference for consonant information as a function of attractiveness of decision alternatives. Pers Soc Psychol Bull 1981; 7: 621-6.

[104] Dalgleish T, Hill E, Golden A-MJ, Morrant N, Dunn BD. The structure of past and future lives in depression. J Abnorm Psychol 2011; 120:1-15.

[105] Zajonc RB. The process of cognitive tuning in communication. J Abnorm Soc Psychol 1960; 61: 159-67.

Received: July 16, 2013

Revised: September 16, 2013

Accepted: September 16, 2013

(C) Santos et al.; Licensee Bentham Open.

This is an open access article licensed under the terms of the Creative Commons Attribution Non-Commercial License (http://creativecommons.org/licenses/by-nc/3.0/) which permits unrestricted, non-commercial use, distribution and reproduction in any medium, provided the work is properly cited. 